\title{
AN ALTERNATIVE ENVIRONMENTAL MONITORING APPROACH TO NONINDIGENOUS SPECIES INTRODUCED FOR MARICULTURAL PURPOSES: THE CASE OF Kappaphycus alvarezii (RHODOPHYTA, SOLIERIACEAE) CULTIVATION IN BRAZIL
}

\author{
Natalia Pirani Ghilardi ${ }^{1 *}$, Leila Hayashi ${ }^{3}$, Flávio Berchez ${ }^{1}$, Nair Sumie Yokoya ${ }^{2}$ \& Eurico Cabral \\ de Oliveira ${ }^{1}$ \\ ${ }^{1}$ Inst. Biociências, Universidade de São Paulo - Rua do Matão, 277 CEP 05508-900 SP- Brazil. \\ ${ }^{2}$ Inst. Botânica, Secretaria de Estado do Meio Ambiente, São Paulo CP 3005 CEP 01061-970, São Paulo - Brazil. \\ ${ }^{3}$ Centro de Ciências Biológicas, Universidade Federal de Santa Catarina, Depto BEG, Campus Universitário - Trindade - CEP 88040-900, Florianópolis, \\ Santa Catarina, Brazil. \\ * Corresponding author: phone 5511 3091-7555, fax: 5511 3091-7547, E-mail: natalinoel@gmail.com
}

\begin{abstract}
The introduction of exotic species has been one of the alternatives to meet the growing interest in aquacultural products in Brazil. However the practice is controversial, since the mechanisms and consequences of most invasions are unpredictable. The exotic species Kappaphycus alvarezii is a commercially important red seaweed from which carrageenan is extracted, that was experimentally introduced in Brazil in 1995. Its environmental spread was periodically monitored since its introduction, but truly effective monitoring relies on consistent previous knowledge about the structure and functioning of the natural communities in the cultivation areas. This work introduces an integrative, rapid and comprehensive evaluation method named Physiognomic Assessment of Hard Bottom Benthic Communities. This method is already being used for describing communities is an alternative tool that can rapidly monitor the possible impacts of the cultivation of nonindigenous species.
\end{abstract}

Keywords: Community ecology, introduced species, Kappaphycus alvarezii, monitoring, rocky shore.

\section{RESUMO}

ABORDAGEM ALTERNATIVA PARA O MONITORAMENTO AMBIENTAL DE ESPÉCIES EXÓTICAS INTRODUZIDAS PARA FINS DE MARICULTURA: O CASO DO CULTIVO DE Kappaphycus alvarezii (RHODOPHYTA, SOLIERIACEAE) NO BRASIL. A introdução de espécies exóticas tem sido uma das alternativas para atender a crescente demanda de produtos derivados da aqüicultura. Este tema gera controvérsias, já que os mecanismos e efeitos da grande maioria das invasões ainda são desconhecidos. A espécie exótica Kappaphycus alvarezii, uma alga vermelha comercialmente importante como fonte de carragenana, foi introduzida experimentalmente no Brasil em 1995. Desde então, monitoramentos ambientais constantes têm sido realizados para controlar a dispersão das plantas. Um conhecimento prévio sobre a estrutura e funcionamento das comunidades naturais é necessário para um monitoramento efetivo. Este trabalho sugere o uso de um método de avaliação extensivo, rápido e integrador, denominado Levantamento Fisionômico de Comunidades Marinhas Bentônicas, que já é usado para descrição de comunidades, como uma ferramenta alternativa para o monitoramento de possíveis impactos que podem ser causados pelo estabelecimento desses cultivos.

Palavras-chave: Ecologia de comunidades, espécies introduzidas, Kappaphycus alvarezii, monitoramento, costão rochoso.

\section{INTRODUCTION OF EXOTIC SPECIES AND} ENVIRONMENTAL CONSEQUENCES

The demand for marine organisms and their subproducts for food is steadily increasing in the last years, and cultivating exotic species has been one of the adopted strategies to meet the growing market.

The introduction of non-native species for aquaculture purposes is a polemic issue. Gollasch (2006) stated that all non-indigenous species are to 
be regarded as potentially harmful until it is proven that the risks involved are low. Some authors consider biological invasions in marine habitats a threat to the composition and structure of native communities (Critchley et al. 1990, Walker \& Kendrick 1998, Balata et al. 2004, Gribben \& Wright 2006, Piazzi \& Ceccherelli 2006). There are evidences implying that changes caused by numerous introductions in a single region can synergistically operate as biological disturbances and pave the way for new invasions, a phenomenon called "invasional meltdown" (Simberloff \& von Holle 1999). Some instances of introduced seaweeds which later became invaders and caused significant ecological and economic impact are Caulerpa taxifolia (Vahl) C. Agardh, Caulerpa racemosa (Forsskål) J. Agardh, Codium fragile ssp. tomentosoides (van Goor) P.C. Silva, Sargassum muticum (Yendo) Fensholt, and Undaria pinnatifida (Harvey) Suringar (Schaffelke et al. 2006). Invasive macroalgae are considered especially worrisome as they can alter both the ecosystem structure and its function by monopolizing space, acting as ecosystem engineers, altering foodwebs, and spreading from their initial point of introduction through efficient dispersal capacities (Thresher 1999).

On the other hand, Briggs (2007) considers that none of the recent studies regarding the effects of marine invaders show any indication of extinctions or loss of biodiversity. According to this author, the introduction of exotic species may, in fact, increase biodiversity, helping the creation of stable ecosystems with high levels of competition and resistance to new invasions.

In any case, since the mechanisms and effects of most invasions are unknown (Balata et al. 2004, Schaffelke et al. 2006), they should be very carefully considered (Assad \& Burstzyn 2000). Although it is impracticable to produce anything without causing environmental alteration, impact on the environment can be reduced to a minimum, avoiding reduction of biodiversity or harm to any natural resource (Valenti 2000).

Given that the environmental effects of the introduction of species with aquacultural purposes are not accidental, there should always be available information of the native distribution of the populations and communities before the introduction. This information is needed to base long-term monitoring programs (Underwood 1990, Villaça 1990, Buschmann et al. 1996).

The nonindigenous species Kappaphycus alvarezii (Doty) Doty ex P.C. Silva, a commercially important red algae that is the source of the phycocolloid carrageenan widely utilized in food, pharmaceutical and cosmetic industries, was experimentally introduced in Brazil in 1995 under the surveillance of the Brazilian Environmental Institution (IBAMA) (Paula et al. 1999, 2002, Paula \& Pereira 2003, Hayashi et al. 2007a, b). The necessary procedures included a quarantine period of 10 months of unialgal culture in the laboratory before the transplantation to the sea. Its spread has been periodically monitored ever since and other preventive measures are being taken, like placing nets under the cultivation raft to avoid the dispersion of loose plants.

In spite of all the care, the environmental monitoring of nonindigenous species being cultivated in Brazil is imperative and a previous record of the structure and functioning of the natural communities in the monitored area is necessary to support an effective monitoring process.

Herein is presented a quicker alternative to the traditional ecological methods of monitoring introduced species for mariculture and evaluation of possible impacts.

\section{PHYSIOGNOMIC ASSESSMENT AS A TOOL FOR MONITORING}

Although Brazil has a vast area of cultivable inshore waters suitable for aquaculture (Oliveira Filho 1977), the biological interactions within these environments are poorly known. Furthermore, there are few studies about biodiversity focusing on community structure, thus only an small fraction of the Brazilian coast of about $3,500 \mathrm{~m}^{2}$ was sampled (Ghilardi \& Berchez 2008). There is a paucity of previous knowledge to base other studies, making any monitoring attempt difficult.

Berchez et al. (2005) proposed the use of landscape ecology perspective as a fast and comprehensive alternative to study and monitor rocky shore communities. This strategy is referred to as "Physiognomic Assessment Method", divided in four approaches based on an operational unit called "settlement": defined as the component of the seascape 
heterogeneity represented by one or some structuring species, which illustrates each homogeneous facet of the rocky shore landscape mosaic. Each settlement is related to a characteristic habitat.

Approach n. 1 is the characterization and initial description of the settlements and respective dominant species in the study area. All macroscopically identifiable settlements are discriminated through visual estimation. A file for each one is created containing a detailed description of the settlement and the environmental conditions in which it is generally found (e.g. substrate features, water motion, irradiance). Photographs are included, aiding posterior identification of that settlement in the field.

Approach n. 2 is the surveying of the georeferenced spatial (horizontal and vertical) distribution of the settlements and how it varies with time. The horizontal distribution is determined with key markers over the rocky shore with the aid of a GPS. Between these key points, a graded rope marked every $1 \mathrm{~m}$ is used to increase precision and avoid GPS's bias accumulation. The horizontal start and end of every settlement on the rocky shore is then annotated according to this scale, being the distance values converted into latitude and longitude coordinates. A vertical ruler or a depth meter is used to determine the maximum vertical variation of the settlements in relation to 0.0 tide level. Samplings are repeated every season to detect temporal variations in the communities' structure.

Approach n. 3 is the quantitative evaluation of the spatial and temporal distribution of each settlement. Sampling units are randomly positioned in the study area, represented by digital images obtained with a digital camera in a watertight compartment attached to a frame that enables obtaining photographs of a constant size. With the aid of a digitizing table in the laboratory, the area of each settlement over the images can be manually determined, and this area is converted into number of pixels and the relative percentage coverage can be calculated. The percentage coverage is used as primary descriptor.

Approach n. 4 is the qualitative and quantitative evaluation of the specific composition of each settlement. This approach aims at detailing settlements' structure while also evaluating their constancy in space and time. Organisms are sampled at random within the chosen settlement(s) and identified down to the lowest taxonomic level possible by the usual methods of marine benthic ecology studies.

The described method can rapidly and comprehensively perform early descriptions of hard bottom benthic communities for later use in monitoring programs.

The approach n. 2 is of especial interest to environmental monitoring for being general and integrative, besides being cheaper than the commonly used monitoring procedures, like some chemical quantization methods for pollutants (Levine 1984). With this approach, a researcher could dive in the area surrounding Kappaphycus cultivations to analyze the distribution of the settlements using a GPS, marked ropes and a depth meter. Approach n. 2, besides contributing to determine the natural communities of a region, which is in itself valuable for the knowledge about the ecosystem, also allows predicting alterations in their structure in consequence of the introduction of a new species.

If there is a need for quantitative data, the approach n. 3 can be used, in association or not with the approach n. 2. Settlements can be easily recognized from digital photographs (Pereira 2007). Such images could be stored as evidence in databases for later verifications or new analyses (Foster et al. 1991), and are, thus, very useful to monitoring studies.

\section{CONCLUSIONS AND SUGGESTIONS}

Brazil presents a great potential for aquaculture, but nonindigenous species are usually introduced for cultivation because there are few native species suited to commercial cultivation. However, it should be stressed that cultivation in a commercial scale causes environmental impact, and one way of preventing and foreseeing them is monitoring the natural communities of coastal areas around cultivated areas.

Given the scarcity of studies about the structure of consolidate substrate communities in Brazil and their utility to monitoring programs, the "Physiognomic Assessment Method” would come as an important tool, for it allows a initial qualitative and/or quantitative description of communities and can be employed to detect and monitor possible alterations in the composition and distribution of the structuring organisms of the 'settlements'. 
The method seems of especial interest for Kappaphycus alvarezii cultivations in Brazil, since this species is of a size that allows easy identification in the field and through photographs. Moreover, Kappaphycuscultivation is currentlyunderlegalization in some regions, and there are indications that environmental monitoring will become compulsory for commercial-scale cultivation.

ACKNOWLEDGEMENTS: We are thankful to FAPESP (process $02 / 07412-8$ ) and CNPq (process 140787/2004-6) for the financial support.

\section{REFERENCES}

ASSAD, L.T. \& BURSTZYN, M. 2000. Aqüicultura sustentável. Pp 33-70. In W.C. Valenti, C.R. Poli, J.A. Pereira \& J.R. Borghetti, (eds). Aqüicultura no Brasil. Bases para um desenvolvimento sustentável. Ministério da Ciência e Tecnologia, Conselho Nacional de Desenvolvimento Cientifico e Tecnológico, Brasília. 399p.

BALATA, D.; PIAZZI, L. \& CINELLI, F. 2004. A comparison among assemblages in areas invaded by Caulerpa taxifolia and C. racemosa on a subtidal Mediterranean rocky bottom. Marine Ecology, 25: 1-13.

BERCHEZ, F.A.S.; ROSSO, S.; GHILARDI, N.P.; FUJII, M.T. \& HADEL, V.F. 2005. Characterization of hard bottom benthic communities: the physiognomic approach as an alternative to traditional methodologies. Pp 207-220. In. Sociedade Brasileira de Ficologia, org. Formação de Ficólogos: um compromisso com a sustentabilidade dos recursos aquáticos. Museu Nacional, Série Livros, Rio de Janeiro. 562p.

BRIGGS, J.C. 2007. Marine biogeography and ecology: invasions and introductions. Journal of Biogeography, 34: 193-198.

BUSCHMANN, A.H.; LÓPEZ, D.A. \& MEDINA, A. 1996. A review of the environmental effects and alternative production strategies of marine aquaculture in Chile. Aquacultural Engineering, 15: 397-421.

CRITCHLEY, A.T.; FARNHAM, W.F.; YOSHIDA, T. \& NORTON, T.A. 1990. A bibliography of the invasive alga Sargassum muticum (Yendo) Fensholt (Fucales, Sargassaceae). Botanica Marina, 33: 551-562.

FOSTER, M.S.; HARROLD, C. \& HARDIN, D.D. 1991. Point vs. Photo quadrat estimates of the cover of sessile marine organisms. Journal of Experimental Marine Biology and Ecology, 146: 193-203.

GHILARDI, N.P. \& BERCHEZ, F.A.S. 2008. Current knowledge status on the ecology of hard bottom benthic communities in brazil and the need for new approaches. Oecologia Brasiliensis, 12: 197205.

GOLLASCH, S. 2006. Overview on introduced aquatic species in European navigational and adjacent waters. Helgoland Marine Research, 60: 84-89.

GRIBBEN, P.E. \& WRIGHT, J.T. 2006. Invasive seaweed enhances recruitment of a native bivalve: roles of refuge from predation and the habitat choice of recruits. Marine Ecology Progress Series, 318: 177-185.

HAYASHI, L.; OLIVEIRA, E.C.; BLEICHERLHONNEUR, G.; BOULENGUER, P.; PEREIRA, R.T.L.; VON SECKENDORFF, R.; SHIMODA, V.T.; LEFLAMAND, A.; VALLÉE, P. \& CRITCHLEY, A.T. 2007a. Carrageenan analyses of Kappaphycus alvarezii (Rhodophyta, Solieriaceae) cultivated in different conditions in Ubatuba Bay, São Paulo, Brazil. Journal of Applied Phycology, 19: 505-511.

HAYASHI, L.; PAULA, E.J. \& CHOW, F. 2007b. Growth rates and carrageenan analysis of four strains of Kappaphycus alvarezii (Rhodophyta, Gigartinales) farmed in the subtropical waters of São Paulo State, Brazil. Journal of Applied Phycology, 19: 393-399.

LEVINE, H.G. 1984. The use of seaweeds for monitoring coastal waters. Pp 189-212. In: L.E. Shubert, (ed.) Algae as ecological indicator. Academic Press, London. 434p.

OLIVEIRA FILHO, E.C. 1977. Algas marinhas bentônicas do Brasil. Livre Docência, Universidade de São Paulo, São Paulo. 407p.

PAULA, E.J. \& PEREIRA, R.T.L. 2003. Factors affecting growth rates of Kappaphycus alvarezii (Doty) Doty ex. P. Silva (Rhodophyta, Solieriaceae) in subtropical waters of São Paulo State, Brazil. Pp 381-388. In. A.R.O. Chapman, R.J. Anderson, V.J. Vreedland \& I.R. Davison, editors. 17th International Seaweed Symposium. Oxford University Press, Cape Town.

PAULA, E.J.; PEREIRA, R.T.L. \& OHNO, M. 1999. Strain selection in Kappaphycus alvarezii var. alvarezii (Solieriaceae, Rhodophyta) using tetraspore progeny. Journal of Applied Phycology, 11: 111-121.

PAULA, E.J.; PEREIRA, R.T.L. \& OHNO, M. 2002. Growth rate of carragenophyte Kappaphycus alvarezii (Rhodophyta, Gigartinales) introduced in subtropical waters of São Paulo State, Brazil. Phycological Research, 50: 1-9.

PEREIRA, A.P.V. 2007. Caracterização fisionômica da comunidade marinha bentônica de substrato consolidado do infralitoral no costão oeste da Enseada das Palmas, Parque Estadual da Ilha Anchieta, Ubatuba-SP, Brasil. Tese de Doutorado, Universidade de São Paulo, São Paulo. 335p.

PIAZZI, L. \& CECCHERELLI, G. 2006. Persistence of biological invasion effects: recovery of 
macroalgal assemblages after removal of Caulerpa racemosa var. cylindracea. Estuarine, Coastal and Shelf Science, 68: 455-461.

SCHAFFELKE, B.; SMITH, J.E. \& HEWITT, C.L. 2006. Introduced macroalgae: a growing concern. Journal of Applied Phycology, 18: 529-541.

SIMBERLOFF, D. \& VON HOLLE, B. 1999. Positive interactions of nonindigenous species: invasional meltdown? Biological Invasions, 1: 21-32.

THRESHER, R.E. 1999. Key threats from marine bioinvasions: a review of current and future issues. Pp. 24-36. In. J. Pederson, editor. Marine Bioinvasions, Proceedings of the First National Conference. Massachusetts Institute of Technology, Sea Grant College Program, Boston. $127 p$.

UNDERWOOD, A.J. 1990. Experiments in ecology and management: their logics, functions and interpretations. Australian Journal of Ecology, 15: 365-389.

VALENTI, W.C. 2000. Introdução. Pp 25-32. In W.C. Valenti, C.R. Poli, J.A. Pereira \& J.R. Borghetti, (eds). Aqüicultura no Brasil. Bases para um desenvolvimento sustentável. Ministério da Ciência e Tecnologia, Conselho Nacional de Desenvolvimento Cientifico e Tecnológico, Brasília. 399p.

VILLAÇA, R.C. 1990. Metodologia de amostragem em costões rochosos. Abordagem fitossociológica. Publicação ACIESP, 71: 1-12.

WALKER, D.I. \& KENDRICK, G.A. 1998. Threats to macroalgal diversity: marine habitat destruction and fragmentation, pollution and introduced species. Botanica Marina, 41: 105-112.

Submetido em 10/01/2008. Aceito em 28/03/2008. 